\title{
ESTETIKA FOTOGRAFI JURNALISTIK DALAM KAITAN NILAI KEBAIKAN DAN KEBENARAN, OLAH RASA, DAN SINESTESIA
}

\author{
Novan Jemmi Andrea \\ Pewarta Foto Koran Seputar Indonesia, Pengajar Fotografi, dan Mahasiswa Program Studi \\ Penciptaan Seni, Program Pascasarjana ISI Yogyakarta \\ Jln. Suryodiningratan No. 8, Yogyakarta \\ No. HP. 085246076267, E-mail: novan.jemmi@gmail.com
}

\begin{abstract}
ABSTRAK
Fotografi jurnalistik menjadi salah satu cabang dari pengelompokan besar di bidang fotografi, selain fotografi seni dan fotografi komersial. Sebagai salah satu bidang seni, fotografi jurnalistik tentunya memiliki konsep estetika tersendiri, bahkan konsep estetikanya sangat berkaitan dengan "rasa", sebuah konsep abstrak mengenai proses peresapan sesuatu dalam diri manusia yang bahkan tidak dapat sepenuhnya dideskripsikan. Pemahaman konsep estetika merupakan proses dialektis berkaitan dengan persoalan lain seperti filsafat, sosial, politik, budaya, dan ekonomi sehingga nilai-nilai kebaikan dan kebenaran sering muncul dalam ragam diskusi estetika. Perkembangan pendekatan konsep proses penciptaan yang melibatkan penonton dan berupaya menyajikan berbagai rangsangan bagi pancaindera menuntut kemampuan dalam olah rasa lainnya, yaitu mengoneksikan pancaindera. Konsep yang berkaitan dengan hal tersebut dikenal dengan istilah synaesthesia (sinestesia), sebuah konsep di mana pancaindera bekerja bersama sekaligus saat merespons sebuah rangsangan sehingga akan menimbulkan sensasi yang melebihi ungkapan satu pancaindera saja. Pemahaman estetika dengan berbagai pendekatan tersebut merupakan proses apresiasi aktif yang bertujuan untuk mengungkap kemungkinan-kemungkinan pewacanaan baru dalam perkembangan fotografi jurnalistik.
\end{abstract}

Kata kunci: estetika, kebenaran, kebaikan, sinestesia

\section{ABSTRACT}

Photojournalism Aesthetic in Regards to the Value of Goodness and Truth, Feeling, and Synaesthesia. Photojournalism becomes one of the branches of a large group in the field of photography in addition to art photography and commercial photography. Great photojournalism is a strange sort of art. Photojournalism allows people to get close to events on the ground, so that people may better understand them as they unfold. This is an abstract concept about the impregnation which cannot be fully described. Understanding the concept of aesthetics is a dialectical process associated with other problems such as philosophy, social, political, cultural, and economic so that the values of goodness and truth often comes in a variety of aesthetic discussion. Developments in the approach to the concept and creation process that involves the audience and trying to present a wide range of stimuli for the senses require proficiency in another sense though, that connected the all senses. Concepts related to the case known as synaesthesia, a neurological phenomenon in which one or more sensory modalities are linked. Aesthetic understanding of the various approaches is an active appreciation process that aims to uncover the possibilities of a new discourse on development of photojournalism.

Keywords: aesthetics, truth, goodness, synesthesia 


\section{PENDAHULUAN}

Awalnya fotografi tidak dianggap sebagai salah satu cabang seni karena latar belakang anggapan terhadap proses fotografi yang terlalu bergantung pada mesin dan tidak perlu pendidikan khusus dalam proses penciptaannya serta hasil akhirnya yang memungkinkan untuk digandakan dengan massal. Bahkan dalam sebuah esai, Walter Benjamin menyatakan tentang bergesernya "aura" dalam sebuah seni pada era reproduksi mekanik, termasuk di dalamnya adalah kegiatan fotografi yang memang memungkinkan untuk membuat salinan yang lebih banyak dibanding seni lainnya sehingga bisa jadi penghargaan dan reaksi publik pada seni pun bergeser.

"The presence of the original is the prerequisite to the concept of authenticity [...]. One might subsume the eliminated element in the term "aura" and go on to say: that which withers in the age of mechanical reproduction is the aura of the work of art" (Benjamin, 1968:220-221).

Sejatinya seorang fotografer tetap memiliki keleluasaan dan hak sepenuhnya dalam menentukan ide, konsep, dan melakukan proses kreatif mengekspresikan diri seperti halnya seniman lain sehingga karyanya tetap memiliki aura dan karakter. Meskipun harus menggunakan mesin dan memanfaatkan teknologi dalam proses penciptaan karya seninya hingga proses penampilan akhirnya, fotografer juga melewati proses kontemplatif untuk mengusung nilai-nilai estetis dalam setiap karyanya. Fotografi menjadi bagian dari seni rupa dua dimensi bersama dengan gambar, lukisan, seni grafis, mozaik, dan kolase.

Beban fungsi lain yang diemban fotografi jurnalistik menjadikannnya berada dalam wilayah seni terapan, yaitu "[...] jenis seni yang kehadirannya justru karena dimanfaatkan untuk kepentingan lain selain ekspresi estetik, semisal [...] kebutuhan praktis dalam kehidupan seharihari" (Soedarso SP, 2006:101). Munculnya beragam media massa cetak dan online turut andil secara aktif menjadikannya salah satu sajian utama untuk penyampaian pesan dan informasi yang memiliki nilai berita tentang suatu penggalan peristiwa faktual kepada khalayak.

Penghadiran karya fotografi jurnalistik tentunya bermula dari konsep dan ide dasar yang berkaitan erat dengan salah satu karakter fotografi jurnalistik, yaitu kemanusiaan. Hubungan pribadi manusia sebagai individu, satu individu dengan individu lain, manusia dengan lingkungan sosial sekitar, bahkan manusia dengan alam merupakan wilayah penggalian ekspresi bagi seorang fotografer jurnalistik yang dewasa ini sering disebut sebagai pewarta foto. Pola penciptaan di wilayah tersebut memunculkan dorongan untuk menggugah olah rasa hingga memunculkan simpati dan empati, sekaligus memancing perbincangan mengenai persoalan estetika dalam perspektif yang lebih luas berkaitan dengan nilai-nilai yang terkandung dalam sebuah foto, selain tentunya adalah keindahan objektif secara visual yang mampu memukau sehingga menarik perhatian mata penikmat foto untuk mengamati dan mengapresiasi karya terlebih dahulu.

Nilai kebaikan dan kebenaran menjadi sedikit persoalan yang selalu muncul dalam pembahasan fotografi jurnalistik. Pertanyaan yang sering muncul adalah mengenai etika moral, serta kesahihan sebuah foto yang ditampilkan karena manusia dengan berbagai latar belakang pengalaman estetisnya memiliki pola pengamatan tersendiri saat mengapresiasi setiap sajian karya fotografi jurnalistik. Pertanyaan tentang kedua nilai tersebut 
tentulah sangat subjektif sehingga yang sangat memungkinkan dalam membahasnya adalah dengan memunculkan pertanyaan mendasar kebaikan dan kebenaran yang mana, menurut siapa, dalam kondisi seperti apa sehingga pada akhirnya memunculkan kesepakatan logis.

Selanjutnya, menyadari tetang perkembangan wawasan dan semakin terbukanya akses terhadap kecanggihan teknologi dewasa ini, sensasi rasa oleh ragam rangsangan yang berkaitan dengan pencerapan inderawi bisa diwujudkan sekaligus dalam sebuah karya. Misalnya, seolah-olah dapat mencium bau busuk menyengat dari tumpukan sampah, padahal tidak sedang benar-benar membau, tetapi hanya melihat sebuah foto tempat pembuangan akhir sampah yang menampakkan seseorang yang menutup hidup dengan kening berkerut saat melintas di depan tumpukan sampah tersebut. Koneksi dua indera atau lebih tersebut dikenal dengan proses sinestesia, yaitu terhubungnya pancaindera dalam menerima sebuah rangsangan yang sejatinya hanya dapat nyata-nyata dicerap oleh satu indera saja, namun indera lainnya bekerja bersamaan dalam memunculkan sensasi. Proses itu tidak hanya dialami oleh penonton foto, melainkan oleh fotografer yang peka untuk mengoneksikan pancainderanya dalam membangun sajian visual yang kuat berdasarkan pengalaman sinestesianya terlebih dahulu.

Mangawali pembahasan, penulis akan menguraikan estetika fotografi terlebih dahulu sebelum mengaitkannya dengan fotografi jurnalistik sebagai seni terapan, lalu dilanjutkan mengaitkannnya dengan nilai kebaikan dan kebenaran, olah rasa, serta konsep sinestesia sebagai pengayaan wawasan mengenai estetika fotografi jurnalistik. Tulisan ini akan diakhiri dengan kesimpulan yang akan menguraikan pemikiran penulis mengenai konteks estetis yang menguatkan proses penyampaian pesan.

\section{ESTETIKA FOTOGRAFI JURNALISTIK DALAM KAITAN DENGAN NILAI KEBAIKAN DAN KEBENARAN}

Banyak pembahasan yang menghubungkan seni dengan keindahan. Membahas keindahan berarti menggali ide tentang estetika sebuah konsep perseptual tentang keindahan, "[...] yang berasal dari bahasa Yunani 'aisthçsis' yang artinya persepsi. Soedarso SP (2006:13) mendefiniskan persepsi sebagai aktivitas 'melihat' melalui penginderaan sehingga segala hubungan pencerapan inderawi mengenai sesuatu yang mengacu pada keindahan atau hal yang menyenangkan atau bahkan yang lebih dari itu tentang hal yang luar biasa dan bernilai lebih tinggi merupakan wilayah pembahasan konsep estetika.

"[...] apa yang disebut seni atau kesenian itumeliputi penciptaan dari segala macam hal atau benda yang karena keindahan bentuknya senang orang melihat atau mendengarnya. Dari rumusan ini dapat disebutkan bahwa yang paling pokok bagi perumusnya adalah bahwa seni itu indah dan barang yang indah itu menyenangkan untuk dilihat atau yang mendengarnya" (Soedarso SP, 2006:66).

Merasakan keindahan menyertakan pengalaman-pengalaman, sudut pandang, dan pengaruh lingkungan sebagai panduan sebelum akhirnya tiba pada sebuah penilaian atau kesimpulan tentang keindahan itu sendiri. Seseorang yang memiliki pengalaman pembelajaran dan pendidikan tentang seni dan estetika tentunya dapat menilai sebuah keindahan dengan sudut pandang yang telah diajarkan, namun bagi yang belum pernah 
mengalami pembelajaran akan hal tersebut konsep keindahan sangat mungkin merupakan wujud kesenangan semata. Dengan demikian, persepsi yang dilakukan hanya bersifat spontan, misalnya karena seseorang senang dengan warna hijau maka saat melihat sebuah karya seni yang menyajikan dominasi warna hijau akan dianggap bagus, walaupun mungkin secara komposisi cenderung biasa-biasa saja. Sederhananya, dalam konteks persepsi keindahan sangat sulit diukur sehingga keindahan didekati dengan sebuah nilai estetis baik dari sudut pandang objektif maupun subjektif.

Di sisi objektif keindahan bisa diukur dari tampilan sebuah karya seni yang mencakup keseluruhan yang tampak dan bisa diamati seperti bentuk, warna, penempatan objek, komposisi, ekspresi, gerak, dan suara. Sisi subjektifmenggali persoalan di luar yang tampak, misal konteks penciptaan dan isu yang melatarbelakangi penghadiran karya, kesesuaian dengan lingkup masyarakat tempat karya dihadirkan, dan pesan yang diangkat oleh seniman dalam karyanya sehingga proses persepsi menjadi lebih mendalam. Di sisi subjektif itulah peran pengalaman empiris individual sangat berperan dalam menyematkan nilai yanng lebih luas. Pengalaman-pengalaman yang diperoleh dari kebiasaan dan pembiasaan dalam kehidupan sosial dalam masyarakat sangat terkait dengan aspek psikologis dan latar belakang sosial sehingga memiliki peranan besar dalam memandu mengolah dan meresapi keindahan. Pengalaman tersebut melahirkan sebuah konsep tentang nilai-nilai keindahan yang dianut oleh masing-masing individu ataupun sekelompok masyarakat. Nilai-nilai estetis tersebut digunakan dalam proses apresiasi karya melalui tanggapan dan penghayatan untuk memperoleh kepuasan. Nilai merupakan esensi, pokok yang mendasar, yang akhirnya dapat menjadi dasar-dasar normatif. Nilai diukur derajat tinggi rendahnya atau kadar yang dapat diperhatikan, diteliti, atau dihayati dalam berbagai objek baik yang fisik maupun abstrak.

Nilai-nilai yang memiliki makna lebih dari sekadar pengertian keindahan tersebut akan dijelaskan dengan terlebih dahulu dimulai dengan pertanyaaan,

"[...] apakah yang dimaksud dengan nilai? Dalam bidang filsafat, istilah nilai sering dipakai sebagai suatu kata benda abstrak yang berarti keberhargaan (worth) atau kebaikan (goodness). Dalam Dictionari of Sociology and Related Sciences diberikan perumusan tentang value yang lebih terperinci lagi sebagai berikut: The believed capacity of any object to satisfy a human desire. The quality of any object which causes it to be of interest to an individual or a group. (kemampuan yang dipercaya ada pada suatu benda untuk memuaskan keinginan manusia. sifat suatu benda yang menyebabkannya menarik minat seseorang atau suatu golongan)" (Dharsono, 2007:8).

Nilai-nilai kebaikan dan kebenaran terkait dengan konteks kehidupan sosial dan pengalaman empiris individu dan masyarakat. Hal tersebut erat kaitannya dengan pembahasan estetika dari sudut pandang filsafat. Menurut Sumardjo (2000:26), "Estetika adalah bagian dari filsafat. [...] digolongkan dalam persoalan nilai, [...].

Saat berbicara tentang kebaikan, maka bisa jadi perdebatan yang muncul diawali dengan pertanyan kebaikan yang bagaimana? Menurut siapa? Baik untuk siapa? Dengan demikian, sejatinya membahas kebaikan pasti juga membahas persoalan sosial tempat karya tersebut dibuat, dihadirkan, dan dipersepsikan. 
Seniman merupakan individu dalam sistem masyarakat. Ia berada dalam pengaruh lingkungan yang dinamis. Kemunculan ide yang dikembangkan menjadi konsep hingga diwujudkan dalam sebuah bentuk karya seni termasuk foto, tentunya dipengaruhi beragam aspek dalam lingkungan sosialnya. Gangguan dari dalam dan luar diri seniman memunculkan kegelisahan, yang mengerucut menjadi ide dan dikembangkan ke wilayah konsep penciptaan. Pelaksanaan pembuatan karya berlangsung dalam balutan diskusi dan referensi yang bertujuan untuk menajamkan pesan melalui simbol-simbol yang diusung dalam karyanya. Mau berbicara apa dengan memakai simbol apa adalah tuntutan yang harus ditunaikan oleh seniman. Hingga pada akhirnya karya tercipta dan dihadirkan untuk diapresiasi oleh masyarakat, pesan yang disampaikan bisa diterima, atau setidaknya bisa diketahui sehingga kesempatan untuk menginterpretasikan makna bisa dilakukan oleh penonton dengan sederhana.

Pengamatan yang dilakukan secara menyeluruh menjadi upaya penggalian tentang nilai kebaikan dan kebenaran dari seni. Baumgarten dalam Sumardjo, (2000:25) menamakan seni itu sebagai termasuk pengetahuan sensoris, yang dibedakan dengan logika yang dinamakan pengetahuan intelektual. [...] estetika adalah keindahan, [...] logika adalah kebenaran. Subjektivitas dalam wilayah persepsi menyebabkan setiap individu memiliki tataran nilainya sendiri-sendiri dalam menilai seni. Hal tersebut juga dilatarbelakangi berbagai aspek di sekitar masing-masing individu, namun yang jelas " [...] seni mengandung aspek nilai intrinsik-artistik, yakni berupa 'bentukbentuk menarik atau indah'. [...] dikemas dalam 'bentuk artistik' (Soemardjo, 2000:137).
Bagan 1 akan menjadi ilustrasi untuk menjabarkan aspek estetika dalam dunia fotografi.

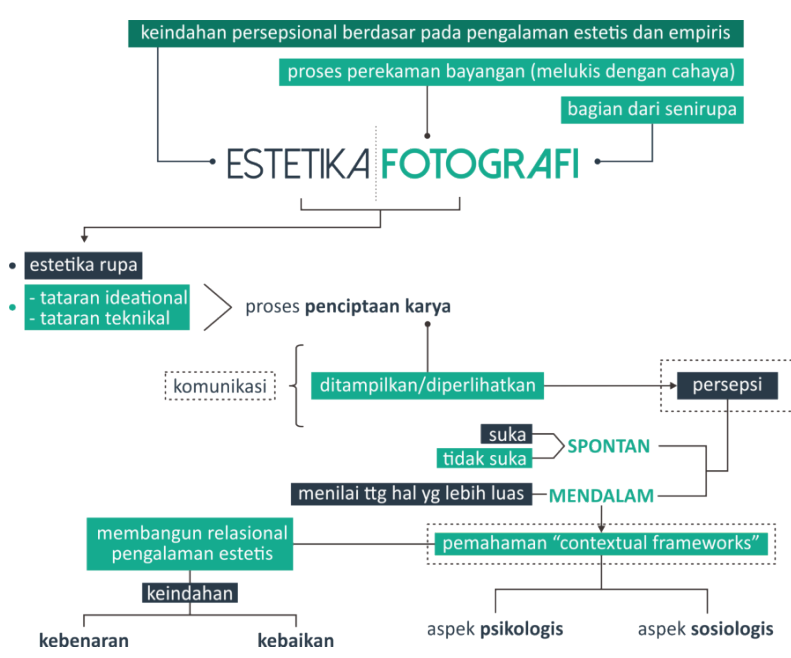

Gambar 1. Bagan konsep pemahaman estetika fotografi

Estetika menjelaskan keindahan persepsional berdasarkan pengalaman estetis dan empiris yang muncul dari pengamatan sehingga keindahan juga melibatkan persepsi penikmat dari tahap mengamati, merepresentasikannya melalui imajinasi, hingga memasuki tahaprefleksi dalam perasaan yang lebih dalam. Memandang keindahan, tidak bisa melulu hanya berdasarkan nilai-nilai formal (mediumistik), namun juga melibatkan nilai yang lebih luas misalnya nilai tentang kehidupan (perasaan, kemanusiaan, nilai kebaikan, dan nilai kebenaran). Fotografi menjadi bagian dari seni rupa dua dimensi yang pada tataran tertentu mengusung konsep estetika yang sama tertutama jika dilihat dari sudut pandang objektif dengan melihat tampilan wujud visualnya.

Jika dalam aktivitas melukis seorang seniman dapat mengungkapkan kreasi dan impresinya terhadap sesuatu di atas kanvas kosong dan memiliki kuasa penuh terhadap penampilan bentuk atau wujud yang akan dilukisnya, seorang fotografer akan memulai dengan tahapan ideasional, yaitu mengamati dan 
memilih dengan berbagai pertimbangan sesuatu yang sudah ada untuk dipotret. Proses pemilihan ini tentunya akan sangat dipengaruhi banyak hal dari perancangan konsep sebagai pengungkapan ide dasar yang dipengaruhi oleh beragam faktor dari dalam maupun dari luar diri fotografer. Ekspresi diri melalui medium fotografi seni bisa dicapai dengan berbagai cara, antara lain dengan memilih objek-objek foto yang unik untuk ditampilkan menjadi karya foto yang 'one of a kind'; [...] (Soedjono, 2007:10).

Pada tataran teknikal, konsep estetika dipengaruhi oleh kecakapan fotografer dalam menguasai teknik-teknik pemotretan antara lain pemahaman akan konsep-konsep komposisi, pencahayaan, efek penggunaan pengaturan tertentu seperti kecepatan rana, dan bukan diafragma untuk menghasilkan foto yang memiliki dimensi kedalaman, serta penggunan alat yang sesuai kebutuhan. Pemahaman konsep estetis ini bahkan dimulai dengan tahap ideasional, terlebih saat berbicara mengenai dunia fotografi jurnalistik ketika berbagai pertimbangan terkait etika-etika dalam masyarakat menjadi panduan dalam proses pemilihan objek dan pemotretan sebelum akhirnya melalui sebuah proses hingga layak dipublikasikan. Tahap selanjutnya pengaplikasian aspek teknis fotografi berupa pencahayaan yang baik pada objek yang dipilih dipadukan dengan efek ruang tajam (area fokus dalam foto) serta dikuatkan dengan komposisi, seperi rule of third, keseimbangan simetris atau asimetris, pemanfataan garis-garis untuk memandu menunjukkan objek utama (point of interes) dan memunculkan pola diagonal yang mengesankan kedalaman dimensi hingga menghasilkan foto yang memiliki daya pukau visual yang baik. Perihal teknis tersebut lalu dikuatkan dengan aspek informatif serta drama dari peristiwa yang diabadikan dalam sebuah foto. Bahkan keutamaan informasi ditegaskan oleh adanya keterangan foto yang selalu hadir bersamaan dengan foto.

Prosesselanjutnyaadalahpublikasikarya foto untuk diakses, diamati, dan dipersepsikan oleh khalayak luas ketika persepsi itu menjadi bagian dari proses komunikasi dan sangat dipengaruhi oleh pengalaman estetis masingmasing individu seperti yang sudah dijelaskan sebelumnya. Persepsi yang merupakan proses mental untuk menghasilkan banyangan tentang segala sesuatu yang dicerap indera. Sering pula persepsi dibarengi dengan imajinasi untuk membangun imaji. Menurut Edward dalam Tedjoworo (2001:21), imajinasi adalah "daya untuk membentuk gambaran (imaji) atau konsep-konsep mental yang tidak secara langsung didapat dari sensasi (pengindraan)". Dengan demikian, imajinasi memainkan peran penting untuk menajamkan imaji yang tidak sempat dicerap secara inderawi secara langsung. Proses membangun imaji tentunya merupakan proses mental karena gambaran tersebut sebenarnya tidak nyata, namun berupaya untuk ditampakkan dalam imajinasi. Proses imajinasi tentunya juga dipengaruhi pengalaman empiris masing-masing individu.

Persepsi dibagi dalam dua tipe, yaitu persepsi yang spontan yang hanya melihat aspek-aspek formal sehingga hanya memunculkan kesepakatan objektif tentang keindahan berdasarkan apa yang dilihat saja dan menghasilkan keputusan untuk suka atau tidak suka. Pada tipe selanjutnya persepsi jauh dilakukan secara mendalam berkaitan dengan perenungan dan peleburan diri dalam upaya memahami konteks penghadiran karya dengan menelaah aspek-aspek sosiologis, psikologis, bahkan aspek antropologis. 
Keterpaduan aspek ideasional dan teknikal pada konsep estetika fotografi jurnalistik diwujudkan dalam bentuk-bentuk yang artistik dan dipadukan dengan kekuatan cerita yang informatif dan faktual guna menghasilkan daya pukau sekaligus daya ganggu yang merangsang mata para penontonuntukmelihat danmenggugah seleranya mengamati dan menelusuri setiap bagian baik yang tampak maupun tersembunyi untuk menemukan makna dan pesan yang sejatinya ingin disampaikan fotografer. Dalam dunia fotografi jurnalistik, keterpaduan seluruh aspek tersebut memiliki peranan yang penting dalam upaya menghasilkan sebuah foto yang bagus secara visual dan kuat informasinya bahkan hingga akhirnya memiliki dampak yang lebih luas bagi kehidupan manusia setelah diapresiasi melalui penilaian dan pengamatan oleh khalayak.

"Seni itu berguna bukan hanya karena keindahan wujudnya, juga karena menyentuh kehidupan nyata. [...] bersifat kontekstual, sesuai dengan apa yang ada di masyarakatnya. [...] nilai sosial, psikologi, keagamaan, moral, dan politik menjadi bahan untuk mewujudkan nilai seni”" (Sumardjo, 2000:149).

Kutipan tersebut merupakan penjabaran dari nilai pragmatis, nilai yang menghubungkan seni dengan dunia nyata. Persoalan nilai dalam foto jurnalistik adalah sebuah nilai-nilai yang berguna dan memengaruhi kehidupan umat manusia. Fungsi informatif sebagai media penyampai pesan menjadi kesempatan bagi sebuah karya fotografi jurnalistik untuk berperan dalam kehidupan umat manusia.

Seperti yang sudah dibahas, nilai estetika sebuah fotografi jurnalistik, tidak hanya melulu didasarkan pada persoalan teknis pemotretan, namun juga pada tataran nonteknis, yaitu berupa kekuatan isi pesan dan informasi serta konteks yang melatarbelakangi penciptaan karya tersebut sehingga persepsi dan pemaknaan bersifat utuh. [...] Setiap pemaknaan harus juga mengacu pada konteks keberadaan (contextual framework) karya fotografinya. Konteks yang dimaksud adalah segala yang berkaitan dengan tujuan (objective) dari penghadiran karya tersebut (Soedjono (2007:26).

Aktivitas penilaian estetika tersebut sebaiknya dipahami sebagai proses yang melibatkan pancaindera baik dari fotografer maupun khalayak penikmat foto.

“[...] Secara garis besar; ada 3 tingkatan basis aktivitas estetik/ artistika:

1. Tingkatan pertama: pengamatan terhadap kualitas material, warna, [...]

2. Tingkatan kedua: penyusunan dan pengorganisasian hasil pengamatan, [...] dengan pertimbangan harmoni, kontras, balance, unity yang selaras atau merupakan kesatuan yang utuh.[...]

3. Tingkatan ketiga: susunan hasil persepsi (pengamatan). Pengamatan juga dihubungkan dengan perasaan atau emosi yang merupakan hasil interaksi antara persepsi memori dengan persepsi visual . tingkatan ketiga ini tergantung dari tingkat kepekaan penghayat (Dharsono, 2007:11).

Persepsi dan pengamatan erat dengan apresiasi yang merupakan bentuk pelaksanaan dari pemahaman estetik, yaitu proses sadar yang dilakukan dalam menghadapi, menafsirkan, dan memahami makna yang terkandung dalam karya seni. Namun, apakah sebuah seni harus indah? Bukankah dalam fotografi jurnalistik banyak foto yang tidak indah karena menyajikan 
kegetiran manusia, konflik berdarah, maupun drama tentang kesengsaraan? Mungkin dalam pandangan sepintas hal tersebut bukanlah sisi keindahan, namun sebuah foto jurnalistik dibuat dengan aturan-aturan fotografis sehingga menghasilkan foto yang artistik. Kalaupun tidak, sekurang-kurangnya ada wujud aplikasi bentuk-bentuk keindahan secara formal, seperti komposisi, pencahayaan, dan momentum yang tepat.

Foto jurnalistik yang baik adalah mengandung kekuatan cerita tentang sebuah peristiwa yang dipotret sehingga dapat menampilkan sebuah "drama" dari penggalan peristiwa yang terjadi. Cerita tersebut pada akhirnya menampilkan dimensi lain daripada hanya sekadar dimensi kajian estetika formal. Kisah yang diusung dalam sajian foto jurnalistik mengandung nilai-nilai yang lebih dalam dan berkaitan dengan kemanusian. Bahkan dalam kondisi tertentu, aspek-aspek estetika formal tersebut menjadi pertimbangan kedua setelah pertimbangan nilai-nilai lain dalam pemilihan sebuah foto yang akan dipublikasikan. Tidak jarang sajian foto yang dipasang dengan ukuran besar di halaman depan surat kabar yang padahal bukan foto dengan komposisi dan warna yang bagus, namun justru mengalahkan foto lain yang memiliki komposisi dan paduan warna yang lebih baik. Pasti ada pertimbangan tertentu hingga foto seperti itu bisa menjadi headline, misalnya saja kekuatan cerita yang disajikan dalam foto tersebut dan dampak yang diharapkan akan ditimbulkan setelah foto tersebut dipublikasikan. Dampak yang dimaksud adalah perubahan dalam masyarakat sebagai respons dari sebuah peristiwa yang disajikan, tentunya perubahan yang diharapkan adalah perubahan menuju arah yang lebih baik. Masyarakat dapat menyerap nilai-nilai lain daripada hanya sekadar perdebatan dangkal mengenai baik buruk sebuah komposisi, warna, dan elemen visual dalam sebuah foto hingga akhirnya nilai-nilai pada dimensi yang lebih dalam tersebut diresapi dan menjadi sebuah pengalaman lain yang menumbuhkan wawasan.

Sebagai karya seni terap yang dipublikasikan, kehadiran fotografi secara umum diiringi dengan penilaian dari para penikmat seni.

“[...] Dalam konteks fotografi tolok ukur penampilannya adalah nilai sekuritas (norma dan etika), nilai fungsi atau daya guna dan nilai estetis (design criteria dan kreativitas-keindahan) yang harus tertampilkan pada kehadiran bentuk hasul keluarannya sebagai output/ end-result produknya (Soedjono, 2007:78).

Ketiga hal tersebut menunjukkan esensi dari nilai estetika yang terkandung dalam domain fotografi. Dengan demikian, dalam hal ini pencarian nilai tentang estetika dalam fotografi jurnalistik harus digali dari sejumlah aspek yang melatarbelakangi penciptaan dan aspek lain yang melatarbelakangi penampilan atau publikasinya.

Misal saja saat menyampaikan persoalan kejujuran dan diwakili oleh ketelanjangan tubuh manusia, bisa saja hal tersebut menimbulkan konflik tersendiri. Di Indonesia, ketelanjangan masih dianggap sebagai hal yang tabu, maka bisa jadi menampilkan sosok tubuh telanjang justru menimbulkan polemik dalam masyarakat. Namun, hal tersebut mungkin akan ditanggapi biasa saja sebagai hal yang lumrah dalam tradisi masyarakat barat sehingga menampakkan pertentangan tentang nilai kebaikan dalam konteks norma dan etika. Nilai kebenaran pun sangat terkait dengan 
konteks sosial dalam masyarakat. Panduan terhadap sesuatu yang dianggap benar sangat dinamis sehingga perdebatan selalu berada pada wilayah subjektif sehingga kemungkinan besar hanya memunculkan kesepakatan yang hampir mustahil menyeluruh. Namun, justru nilai-nilai inilah yang menjadi acuan dalam kajian estetika yang mendalam dalam karya fotografi jurnalistik. Bagaimana sebuah foto yang mungkin tidak menampilkan keteraturan komposisi, namun memiliki kekuatan drama dari sebuah penggalan peristiwa, pada akhirnya justru membawa dampak yang lebih luas dalam peranannya membangun kesadaran manusia. Nilai-nilai tersebut juga mengembangkan wawasan dan pengalaman individu dalam memahami konsep-konsep keindahan yang mendalam sebagai hasil dari persepsi dan renungan kontemplatif terhadap rangsangan visual.

Untuk memudahkan pemahaman tentang persoalan nilai-nilai ini akan dibahas dengan mengambil contoh sebuah foto karya Nick Ut, pewarta foto Associated Press, tentang suasana perang di Vietnam, khususnya kondisi masyarakat yang menjadi korban dari sebuah serangan bom napalm di Desa Trang

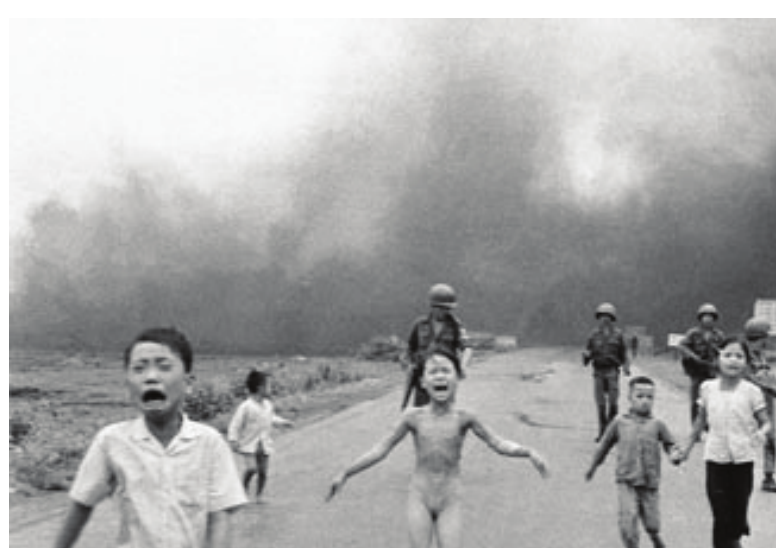

Gambar 2. Foto karya Nick Ut

Sumber: www.abcnews.go.com
Bang, Vietnam Selatan kala itu. Pada 8 Juni 1972, sekitar 40 tahun yang lalu, Nick memotret sekelompok masyarakat yang kebanyakan anak-anak berlari menyelamatkan diri usai dijatuhkannya bom di desa mereka. Dalam fotonya, seorang anak perempuan, yang belakangan diketahui bernama Phan Thi Kim Phuc, telanjang dan berlari sembari membentangkan kedua tangan dengan mimik wajah histeris.

Dari sisi teknis fotografi dan sudut pandang estetika formal, foto ini tampak sebagai foto yang biasa dalam arti komposisinya cenderung datar dan seimbang, walaupun daya pukau dari pusat perhatian utamanya (seorang anak kecil yang telanjang) dan kepulan asap tebal di latar belakang berhasil memancing perhatian penonton. Sajian warna hitam putih pun sebetulnya tidak menampakkan dampak lain yang sebenarnya justru menyajikan kengerian yang luar biasa, yaitu kondisi kulit salah satu anak yang melepuh dan terkelupas akibat bom napalm yang dikenal juga sebagai senjata pembakar karena reaksi kimia yang akan menyebar sesaat setelah bom meledak dan mengakibatkan luka bakar bagi siapa pun yang terkena. Pun demikian dengan posisi objek lain yang saling menumpuk sehingga sekilas mengesankan ketimpangan yang tidak nyaman dipandang. Jika mengacu pada konsep estetika formal, tentunya foto tersebut bukanlah foto yang bagus. Memakai istilah yang sering digunakan fotografer saat ini adalah bahwa foto itu flat.

Ketelanjangan utuh yang ditampilkan juga sejatinya bukan hal yang layak untuk ditampilkan secara luas jika mengacu pada nilai kebaikan terkait etika dan moral. Namun, foto tersebut akhirnya dipublikasikan dan tersebar menjadi sajian utama di halaman muka surat kabar internasional mengalahkan perdebatan 
tentang etika dan sekejap saja memantik protes anti perang di berbagai belahan dunia terutama Amerika Serikat yang kala itu terlibat langsung dalam perang di Vietnam.

Nilai kebaikan etis pada foto tersebut seolah-olah didobrak. Penyajian ketelanjangan bulat mungkin saja menjadi perdebatan diawal, namun nyatanya dengan berbagai proses yang dilalui foto tersebut menyebar dan pada akhirnya menggugah pemahaman lain terkait konsep kebaikan yang lain. Foto tersebut nyatanya mengundang reaksi dan gelombang protes untuk menghentikan perang di Vietnam. Masyarakat tergugah dengan kekuatan sajian visual, menstimulus pengalaman masa lalu terkait perang demi kepentingan ambisius sekelompok pihak, tetapi justru menimbulkan bencana kemanusiaan yang dahsyat dengan menyebabkan banyaknya korban manusia. Foto tersebut memancing amarah untuk mendesak penghentian perang sekaligus memunculkan kepedulian terhadap para korban. Nilainilai kebaikan lain pada akhirnya muncul bukan pada saat foto itu dibuat dan seketika saat ditampilkan, melainkan pascafoto itu berhasil menggugah kesadaran manusia lain untuk berbuat sesuatu yang lebih baik untuk menghentikan dan mencegah kejadian serupa terulang. Jika saja foto tersebut tidak pernah dimuat akibat pertimbangan etika awal tentang ketelanjangan, mungkin saat ini orang tidak pernah tahu tentang peristiwa miris yang dialami masyarakat Vietnam akibat perang kala itu. Justru karena satu hal dikesampingkan terlebih dahulu, akhirnya menimbulkan dampak yang lebih luas, yaitu bagaimana foto tersebut memancing reaksi dari masyarakat internasional yang peduli terhadap kemanusiaan sehingga menuntut perang dihentikan. Saat ini pun dapat disepakati dengan sikap permisif mengenai satu aspek yang tidak sesuai dengan etika moral, yaitu publikasi tentang ketelanjangan, namun dengan kesadaran tersebut justru pada akhirnya disepakati nilai-nilai kebaikan yang lain bagi kemanusiaan, yaitu perjuangan bersama untuk mencegah, menghindari, dan menghentikan peperangan demi kebaikan umat manusia yang lebih luas.

Pada 1992, Phan Thi Kim Phuc mendapat suaka politik di Kanada dan saat ini ia tinggal di sana bersama suami, kedua putranya, dan orang tuanya. Ia juga membuat sebuah yayasan Kim Foundation International, sebuah badan amal untuk membantu anak-anak yang menjadi korban dan menderita akibat perang. Ia pun menjalani hidupnya dalam upaya pelayanan yang menjadi misi yayasannya. Hal tersebut merupakan dampak dari tumbuhnya nilai-nilai kebaikan dalam masyarakat setelah sebuah peristiwa yang diwakili oleh sebuah foto menjadi ikon dari Perang Vietnam muncul mendobrak tatanan etika, namun mampu menumbuhkan nilai kebaikan lain berkaitan dengan kemanusiaan.

Selanjutnya adalah tentang nilai kebenaran. Masih mengacu pada contoh foto tersebut, nilai kebenaran logis dan paling mendasar adalah kebenaran faktual terkait peristiwa yang terjadi, lokasi, dan keberadaan objeknya. Kebenaran logis yang dimaksud berkaitan dengan kenyataan bahwa peristiwa tersebut benar-benar dapat dibuktikan dan ditelusuri dengan bukti-bukti yang ada. Foto tersebut dibuat benar-benar di lokasi perang sesaat setelah dijatuhkannya bom di sekitar lokasi pemotretan sehingga tidak bisa dibantah lagi kenyataan kejadiannya.

Terkait dengan pengetahuan akal budi manusia dan pengetahuan inderawi sebagai bagian dari kondisi sadar akan nilai-nilai 
kebenaran, fotografer memiliki kepekaan estetis berdasarkan pengalaman bertahun-tahun sebagai pewarta foto sehingga secara naluriah foto yang dibuat mencerminkan kemampuan pengolahan akal dan budi sekaligus kepekaan memilih momentum yang tepat dari sebuah peristiwa serta suasana dirasakan fotografer saat berada dilokasi untuk ditransfer kepada penonton yang berada dilokasi lain sesuai apa adanya. Isu yang berkembang tentang kekacauan dan penderitaan akibat perang akirnya bisa diwujudkan dalam sebuah foto. Benar adanya bahwa perang merupakan tindakan yang lebih banyak menimbulkan penderitaan. Tindakan brutal saling menyerang seringkali dilakukan tanpa pertimbangan matang hanya karena ingin segera menguasai atau memenangi peperangan. Selebihnya, kebenaran pun diusung dalam sajian visual yang dapat dikonfirmasi melalui indentifikasi orang-orang yang ada dalam foto, salah satunya adalah Phan Thi Kim Phuc, serta beberapa saudaranya yang hingga kini masih hidup.

Peristiwa tragis benar-benar terjadi, diabadikan secara langsung oleh fotografer, dipublikasikan oleh media massa, memicu perdebatan lain tentang nilai kebenaran pada dimensi lain, yaitu apakah benar perang merupakan tindakan yang benar dan tepat untuk menyelesaikan masalah? Apakah sebuah pencarian kebenaran tidak bisa diperoleh melalui jalan damai? Mungkin benar menurut satu pihak, tetapi tidak benar bagi pihak lain. Namun, yang perlu diingat adalah bahwa sebagai sebuah foto jurnalistik, fungsi yang paling utama adalah keberpihakan kepada kemanusian demi menciptakan keadaan peradaban yang lebih baik.

Pemahaman dan interpretasi karya seni termasuk fotografi jurnalistik dengan pendekatan yang kontekstual mungkin bisa menjembatani persoalan tersebut. Masyarakat bisa mengamati konsteks penghadiran karya tersebut berdasarkan perkembangan isu dan wacana terbaru. Penilaian terhadap kondisi saat perekaman peristiwa berlangsung dibarengi dengan penghargaan atas isi yang terkandung dalam karya dapat dilakukan untuk menggali persoalan yang lebih dalam terkait pesan dan makna yang ingin disampaikan. Keindahan terwujud dalam penghadiran karya hingga proses persepsi untuk menggugah kesadaran, yang pada akhirnya memberikan tawaran pengalaman empiris lain sehingga menghasilkan efek yang menawarkan perubahan paradigma menuju kesenangan dan keindahan pada berbagai aspek saat seluruh isi pesan dapat tersampaikan dan dipahami sebagai sebuah kesatuan utuh dari sebuah karya foto jurnalistik.

\section{OLAH RASA DAN SINESTESIA}

Dalam keseharian, tanpa sadar terusung konsep "rasa" dalam merespons sesuatu. Rasa tersebut mewujud dalam berbagai rupa, namun lebih sering bukan sesuatu yang dapat dideskripsikan secara jelas, seperti kesedihan dan kesenangan. Proses itu juga dipengaruhi oleh stimulus lain seperti pengalaman yang pernah dialami sehingga sebuah konsep dengan asosiasi tertentu tertanam di dalam benak individu. Lebih jauh, nantinya proses tersebut berperan besar dalam menimbulkan simpati dan empati sehingga saat bersinggungan dengan sebuah karya seni, hal itu bisa menjadi jembatan yang mengantar penonton menuju sebuah konsep yang abstrak, yaitu rasa. Merasakan saat mengamati, merasakan untuk masuk dan menggali persoalan esensi dari sebuah tampilan seni. [...] Rasa adalah saripati, esensi, [...], hakikat dari sesuatu. [...] 
hanya dapat disugestikan atau dialami secara mendalam, namun rasa tidak dapat sepenuhnya dideskripsikan (Marianto, 2015:206).

Rasa tidak hanya dialami oleh penonton saat mengamati karya seni, namun juga dialami oleh seniman dan menjadi daya penggerak dalam menciptakan karya. Rasa merupakan sesuatu yang spontan muncul karena suatu stimulus, namun berkembang penjabarannya akibat pola pemikiran tertentu yang terjadi dalam diri individu dan memancing aktivitas lain seperti simpati dan empati sekaligus penilaian terhadap karya seni. Pengungkapan sensasi inderawi baik itu pengelihatan, penciuman, perabaan, pendengaran, dan pengecapan juga sangat dipengaruhi oleh rasa untuk nantinya tindakan pengungkapan sensasi menjadi sebuah realitas yang bisa dipahami secara logis. Seperti dalam bahasan di awal tentang pengamatan seni adalah seni menawarkan imaji menampakkan wujudnya melalui imajinasi dengan mengaktifkan pancaindera untuk mencerap rangsangan sehingga memunculkan sensasi.

Selanjutnya adalah proses interkoneksi pancaindera untuk membangun dan merasakan sensasi saat menerima sebuah rangsangan yang dikenal dengan istilah sinestesia. Sinestesia menjabarkan suatu pengalaman dan kondisi mental dimana seseorang mengamati sesuatu dalam kehidupan dengan mengoneksikan semua inderanya. Kondisi mental tersebut dinyatakan oleh Heyrman (diakses 17 Juni 2015), "The neurological condition 'synesthesia' is a responding to a stimulus of one sense modality with sensations which belong to another sense modality."

Menurut Heyrman, seni bukan sebagai pengalaman sinestesia, melainkan seniman itu sendiri yang mengalami sinestesia dan menghasilkan pengalaman sinestetik (dalam proses berkesenian) untuk menghasilkan karya seni yang memiliki daya ganggu multiindera guna mengungkapkan kepada dunia visi apa yang diusungnya. Bagi seniman, dalam proses sinestetis itulah indera satu dengan indera yang lain mulai menerjemahkan rangsanganrangsangan, mengolah komponen-komponen pembentuk, yang ditransfer menjadi wujud kualitas karya seni. Namun, saat ini penonton pun dapat mengalami sinestesia dalam tindakan apresiasi. Dalam seni, pengalaman sinestetik, pengalaman empiris, dan pengalaman estetis saling terkoneksi dalam kesatuan rasa seperti yang sudah dijelaskan sebelumnya. Hukum kausalitas tentang pancaindera yang saling terkoneksi dengan rasa, ekspresi, pengalaman empiris, dan pengalaman estetis itu mempunyai kualitas sinestetis dan menjadi satu kesatuan yang tidak terpisahkan dalam proses berkarya hingga karya tersebut ditampilkan untuk diapresiasi. Life is a continuous synesthetic experience, seeing, smelling, touching, hearing, tasting - the world discloses itself to us through the sense (Heyrman, diakses 17 Juni 2015).

Pada suatu ketika dalam sebuah kebetulan dua laki-laki berpapasan dengan seorang perempuan yang dari wujudnya menampakkan keanggunan, bentuk tubuh yang seksi, rambut panjang hitam tergurai, berkulit putih, dengan bibir tipis, dan rona wajah yang segar. Seketika itu pula satu di antara kedua laki-laki tersebut berkomentar "Wah, manis juga perempuan itu", yang disambut anggukan setuju laki-laki satunya lagi. Manis? Apanya yang manis? Bahkan perempuan itu bukan orang yang mereka kenal, menyentuh saja tidak pernah apalagi bisa merasakan sesuatu yang manis. Bukankah rasa manis merupakan sensasi dari indera pengecap? Apa laki-laki 
yang mengatakan bahwa perempuan itu manis pernah mengecap (dengan indera pengecap) perempuan itu? Tentulah tidak, karena pernyataan manis itu sebetulnya merupakan asosiasi konsep sensasi yang diasosiasikan dengan sesuatu berupa makanan atau minuman manis yang segar, menyenangkan, dan membawa dampak ketagihan (jika memang suka pada sesuatu yang manis), terlebih jika bisa dinikmati dengan suasana sekitar yang mendukung.

Ilustrasi tersebut menjadi kenyataan sederhana, bahwa sebenarnya sering muncul gejala pengoneksian pancaindera saat menerima sebuah rangsangan. Melihat perempuan berkulit putih mulus, beramput hitam panjang tergerai, dengan bentuk tubuh yang seksi merangsang sensasi inderawi lain tentang sesuatu yang menyenangkan sehingga muncullah konsep rasa manis yang sejatinya hanya bisa dicerap oleh indera pengecap. Melihat seolah-olah bisa merasakan manis dan pahit, mendengar seolaholah bisa sekaligus melihat sebuah bentuk.

Mengacu contoh foto sebelumnya, bisa diamati sebuah rasa yang tampil dalam ekspresi wajah objeknya yang didukung suasana sekitar seperti kepulan asap dan sejumlah tentara. Memulai dengan pengamatan akan elemen-elemen visuat tersebut menimbulkan rasa tentang kesedihan dan ketakutan karena ekspresi wajah yang tampak dari objek yang menjadi pusat perhatiannya diasosiasikan dengan kondisi yang pernah dialami, atau setidak-tidaknya pernah diketahui. Ekspresi yang menunjukkan histeria, sekaligus kesakitan karena jika diamati lebih saksama si anak kecil mengalami luka bakar yang cukup serius. Rasa itu kemudian mendorong indera lain untuk bekerja membangun imajinasi. Jelas terlihat suasana di dalam foto merupakan suasana perang, asap tebal membumbung rupanya merupakan sisa ledakan bom yang dijatuhkan dari pesawat. Tidak butuh waktu lama untuk penonton seolah-olah mendengar suara kegaduhan raung mesin pesawat disambut dentuman keras khas suara bom meledak, pun demikian seolah-olah aroma hangus benda terbakar terasa sensasinya. Samarsamar jeritan-jeritan manusia bercampur aduk dengan teriakan-teriakan lain yang entah apa artinya, namun pada akhirnya menampakkan kengerian, ketakutan, dan kepedihan yang luar biasa. Sang anak yang berlari telanjang dengan ekspresi histeris berhasil menjadi poin utama yang memikat mata penontoon, hingga akhirnya mau mengamati foto daripada hanya sekadar melihat. Pengamatan secara visual secara mendalam memberi kesempatan bagi indera lainnya untuk juga bekerja memunculkan sensasi lain sehingga penonton tidak hanya melihat foto, namun juga sekaligus merasakan peristiwa yang terjadi.

\section{SIMPULAN}

Zaman dan perkembangan beragam aspek yang menyertainya menjadikan seni selalu menyajikan pola pendekatan penciptaan yang baru. Seni murni ataupun seni terapan yang masing-masing memiliki konsep estetikanya sendiri berkembang sebagai ungkapan eskpresi dengan penyampaian yang dimulai dengan pengolahan rasa dan pengorganisasian sensasi inderawi dari seniman hingga diterima dengan rasa dan pencerapan inderawi pula oleh penonton. Foto jurnalistik sebagai seni terapan pun mengusung konsep-konsep tersebut dalam balutan fungsi informatifnya untuk mencapai tujuannya yang tidak melulu hanya berupaya menguatkan daya pukau namun juga daya ganggu yang lebih tajam, hingga akhirnya 
mampu memikat penonton untuk menyelami, mengamati lebih dalam terhadap seuatu yang lebih luas dari pada hanya perkara keindahan mediumistik.

Sebagai sebuah seni terapan yang selalu hadir di tengah-tengah masyarakat, foto jurnalistik juga sangat berkaitan dengan seluruh aspek, baik karya fisiknya, konteks perkembangan zaman yang melingkupi eksistensi penciptaannya, hingga pola interaksi masyarakat luas dalam mengapresiasi.

Seni selalu - secara langsung maupun tidak - merefleksikan kebutuhan, $\quad[\ldots] ;$ pun mencerminkan institusiinstitusi yang mendukung dan menyebarluaskan karya seniman itu, serta dunia sosial-budaya dimana seniman dan institusi bersangkutan jadi bagian dari kehidupan keseluruhan (Marianto, 2011:17).

Persoalannya tidak berhenti pada bagaimana fotografi jurnalistik berkembang merespon kebutuhan masyarakat di tengah perkembangan zaman, namun tentang bagaimana bahwa fotografi jurnalistik juga semakin memiliki daya ganggu terhadap pencerapan inderawi para penikmatnya sehingga pengungkapan tentang nilai-nilai yang lebih luas dapat dicapai dan disebarkan kepada masyarakat.

Keberpihakan kepada kemanusiaan menjadikan foto jurnalistik dituntut untuk memuat nilai-nilai lain yang dimaksudkan untuk menggugah kesenangan melalui kesadaran logis akan sebuah kondisi yang ditampilkan. Kesenangan tidak hanya didapat seketika saat melihat sebuah foto yang bagus dari aspek fotografis, namun kesenangan tersebut tumbuh seiring proses dialektis, pengamatan dan penilaian terhadap keseluruhan muatan nilai dalam sebuah foto jurnalistik. Tidak dapat dikesampingkan juga bahwa daya pukau awal secara kasat mata juga penting bagi sebuah sajian foto jurnalistik. Pewarta foto harus memiliki intuisi ideasional dan jeli memilih objek yang mewakili penggalan peristiwa yang diabadikan dan momentum yang tepat untuk memotretnya sebagai awal pengungkapan nilai-nilai estetis dalam karyanya. Selanjutnya mengatur pencahayaan, komposisi, menyatukan dan mengatur penempatan elemen-elemen viusal lainnya dengan menggerahkan daya pengetahuan teknis-teknis fotografinya agar foto yang dihasilkan menampilkan unsurunsur estetika objektif (meduimistik) sehingga mampu memancing mata penonton untuk melihatnya.

Saat tataran estetika ideasional dan teknikal dipenuhi, serta proses pemilihan yang jeli, foto jurnalistik yang dipublikasikan akhirnya mampu membangun relasi estetis dengan masyarakat luas yang melihat dan mengamatinya. Penonton diajak untuk menyelami karya, membangkitkan rasa untuk memunculkan sensasi lain yang lebih luas dari pada hanya melihat. Pengamatan dikuatkan dengan kondisi mental untuk mengaktifkan seluruh pancaindera saat mengamati dan mengapresiasi sesuai konsep sinestesia. Hingga pada akhirnya pengalaman sinestesia dari pewarta foto dapat berjalan secara paralel diwakili karya fotonya sampai pada penerimaannya oleh penonton. Saat foto semakin menyatukan pencipta, peristiwa, dan masyarakat penontonnya, pengalaman estetis melalui interakssi secara tidak langsung dapat berkembang, memberikan pemahamanpemahaman baru terhadap relasi logis antara keindahan visual dengan keindahan yang diwakili oleh nilai-nilai kenaikan dan kebenaran. Penghargaan terhadap ekspresi 
pewarta foto yang ditunjukkan dalam karya foto mencerminkan tumbuhnya pengalaman estetis penonton serta kedewasaan dalam membangkitkan rasa, mengimbanginya dengan penilaian-penilaian logis tentang nilai kebaikan dan kebenaran sehingga menjadi stimulus bagi perubahan kehidupan yang lebih baik dalam masyarakat, atau jika hal tersebut dianggap terlalu berlebihan setidaknya individu yang melihat dan mengamati dapat menemukan esensi dari sebuah cerita yang dihadirkan dan memahaminya sebagai bagian dari pola kehidupan masyarakat sehingga memperkaya pengalaman yang memandu kehidupannya.

\section{KEPUSTAKAAN}

Dharsono. 2007. Estetika. Bandung: Penerbit Rekayasa Sains.

Effendy, Onong Uchjana. 2003. Ilmu Komunikasi; Teori dan Praktik. Bandung: Remaja Rosdakarya.

Gie, The Liang. 1996. Filsafat Keindahan. Yogyakarta: Pusat Belajar Ilmu Berguna.

Marianto, M. Dwi. 2015. ART \& LEVITATION: Seni dalam Cakrawala Quantum. Yogyakarta: Pohon Cahaya.

Marianto, M. Dwi. 2011. Menempa Quanta Mengurai Seni. Yogyakarta: BP ISI Yogyakarta.

Soedjono, Soeprapto. 2007. Pot -Pourri Fotografi. Jakarta: Penerbit Universitas Trisaksi.

Soedarso Sp. 2006. Trilogi Seni: Penciptaan, Eksistensi, dan Kegunaan Seni, Yogyakarta: BP ISI Yogyakarta.

Sumardjo, Jakob. 2000. Filsafat Seni. Bandung: Penerbit ITB.

Suprapto, Yos. 2009. Teknologi Tepat Guna dalam Konteks Estetika. Yogyakarta: Program Pascasarjana ISI Yogyakarta.

Tedjoworo, H. 2001. Imaji dan Imajinasi. Yogyakarta: Penerbit Kanisius.

Wijaya, Taufan. 2014. Foto Jurnalistik. Jakarta: PT Gramedia Pustaka Utama.

\section{Pustaka Laman}

Heyrman, Hugo. 2005. Art and Synesthesia: in search of the synesthetic experience, http://www.doctorhugo.org/synaesthesia/ art/, (diakses 15 Juni 2015)

$h t t p:$ / / a b c n e ws.go.co m / blogsheadlines/2012/06/the-historicnapalm-girl-pulitzer-image-marks-its40th-anniversary/, (diakses 1 Agustus 2015)

http://dictionary.reference.com/, (diakses 17 Juni 2015) 
